\title{
Assessment of Groundwater Pollution using Aqueous Geo-Environmental Indices, Baiji Province, Salah Al-Din, Iraq
}

\author{
Mahmood F. Abed ${ }^{1} *$, Ghazi Atiya Zarraq ${ }^{1}$ and Salwa H. Ahmed ${ }^{2}$ \\ Department of Applied Geology, College of Sciences, Tikrit University, Tikrit, Iraq \\ Department of Environmental Engineering, College of Engineering, Tikrit University, Tikrit, Iraq \\ Correspondence: $\underline{\text { dr.mahmood@tu.edu.iq }}$
}

\begin{abstract}
Received:
3 October 2021

Abstract

Accepted:

28 November 2021

Published:

28 February 2022

The study area is located in Baiji province characterized by anthropogenic activities which may affect the groundwater quality. Therefore, the present work was intended for assessing groundwater quality and its suitability for drinking. Groundwater samples were collected from 33 different well, then analyzed to determine 20 parameter which are TDS, $\mathrm{Ca}, \mathrm{Mg}$, $\mathrm{Na}, \mathrm{K}, \mathrm{Cl}, \mathrm{SO}_{4}, \mathrm{NO}_{3}, \mathrm{Al}, \mathrm{Cd}, \mathrm{Cr}, \mathrm{Cu}, \mathrm{Fe}, \mathrm{Mn}, \mathrm{Ni}, \mathrm{Pb}, \mathrm{Zn}, \mathrm{As}, \mathrm{B}$ and Se. Nemerow Pollution Index Synthetic Pollution Index, and Pollution Index of Groundwater were used for determining groundwater suitability for human consumption. Nemerow Pollution Index values indicate that groundwater pollution is ranged from seriously to moderately polluted. According to Synthetic Pollution Index results, the water samples were moderately polluted to unsuitable for drinking. Depending on the rating of Pollution Index of Groundwater values, groundwater was polluted.
\end{abstract}

Keywords: Groundwater pollution; Nemerow Pollution Index; Synthetic Pollution Index

\section{Introduction}

Groundwater represents an important and vital natural resource for thousands of people living in the villages. Groundwater is a source for drinking, bathing and other household uses, especially during periods of interruption of drinking water supply (Awadh et al. 2016). For this reason, determining the quality of groundwater for human uses is important in this regard (Abd El- Hamid and Hegazy, 2017). The quality of the groundwater is not only affected by natural factors such as the aquifer lithology, the nature of the interaction between the groundwater and the aquifer material, and the nature of the recharge water (Al-Kubaisi and Al-Sumaidai, 2021) but also can change by human activities either by effecting on the hydrological cycle or by contaminating groundwater systems (Beg et al. 2021; Yang et al. 2017).

Many studies have indicated the harmful effects of heavy metals and metalloids, especially when their concentrations are higher than the permissible limits (Sahoo and Swain, 2020; Gharaat et al., 2020; Sawut et al. 2018). What distinguishes heavy metals and metalloids from other pollutants is that they are durable in the environment and are not easily degradable (Nasrabadi, 2015). Human activities are often a source of pollutants, especially toxic metals. The study area is characterized by two types of human activities, namely, industrial and agricultural activities. The industrial activities include oil refineries, two electrical power plants, a detergent factory, vegetable oil factory, and a fertilizer plant. The agricultural activities include applying pesticides and fertilizers. Both activities add many pollutants

DOI: 10.46717 /igj.55.1B.9Ms-2022-02-25 
that leach into the groundwater, leading to a deterioration of the water quality. The area of study is located in the northern part of Salah al-Din, specifically $5 \mathrm{~km}$ to the north of the city of Baiji lies in between longitude $43^{\circ} 37^{\prime} 10^{\prime \prime}$ to $43^{\circ} 58^{\prime} 52^{\prime \prime}$ and latitude $34^{\circ} 90^{\prime} 10^{\prime \prime}$ to $35^{\circ} 12^{\prime} 10^{\prime \prime}$ (Fig.1). There are some villages in the area, where thousands of people live there. For assessing the quality of groundwater, various indices have been developed and adopted (Swati and Umesh, 2015). The current study aimed to investigate groundwater quality and suitability for drinking and domestic uses via analyzing heavy metals, metalloids and, major ions by a mathematical method. The Nemerow Pollution Index (NPI), Synthetic Pollution Index (SPI), and Pollution Index of Groundwater (PIG) are applied as environmental monitoring tools.

\section{Geology and Hydrogeology}

The area is situated within Hemrin-Makhul Subzone or foothill zone which is distinguished by a thick cover of sediments. The older rocks exposed in the study area is the Fat'ha Formation (Middle Miocene) which is distinguished by the dominating evaporates facies that consist of halite, gypsum, anhydrite and limestone facies which refer to the shallow marine environment (Jassim and Goff, 2006). The outcrops of the Fat'ha formation exposed along the Tigris River to the north of the study area. The Fat'ha Formation is overlaying by the Injana Formation (Upper Miocene) which consists of silty claystone, siltstone, and sandstone with thin layers of gypsum nodules. This formation is exposed in some places along the Tigris River and in Makhul Anticline (Al-Hwez, 2014). The Injana Formation is covered by quaternary deposits (Pleistocene and Holocene) deposits which are represented by river terraces, flood plain deposits, slope sediments, valley fillings, and gypsums soil (Jassim and Goff, 2006). River terraces deposits are consisting of sands, whereas flood plain deposits are consisting of gravel, sand, silt, and clay (Al-Maiyahy, 2004). Hydro geologically, the study area consists of two aquifers, one belongs to the Injana Formation which is characterized by deep wells and it is a confined type according to (Al-Salman, 2013), and the second belongs to the Quaternary deposits which are characterized by shallow wells and it is an unconfined type (AL-Adhmawee, 2013).

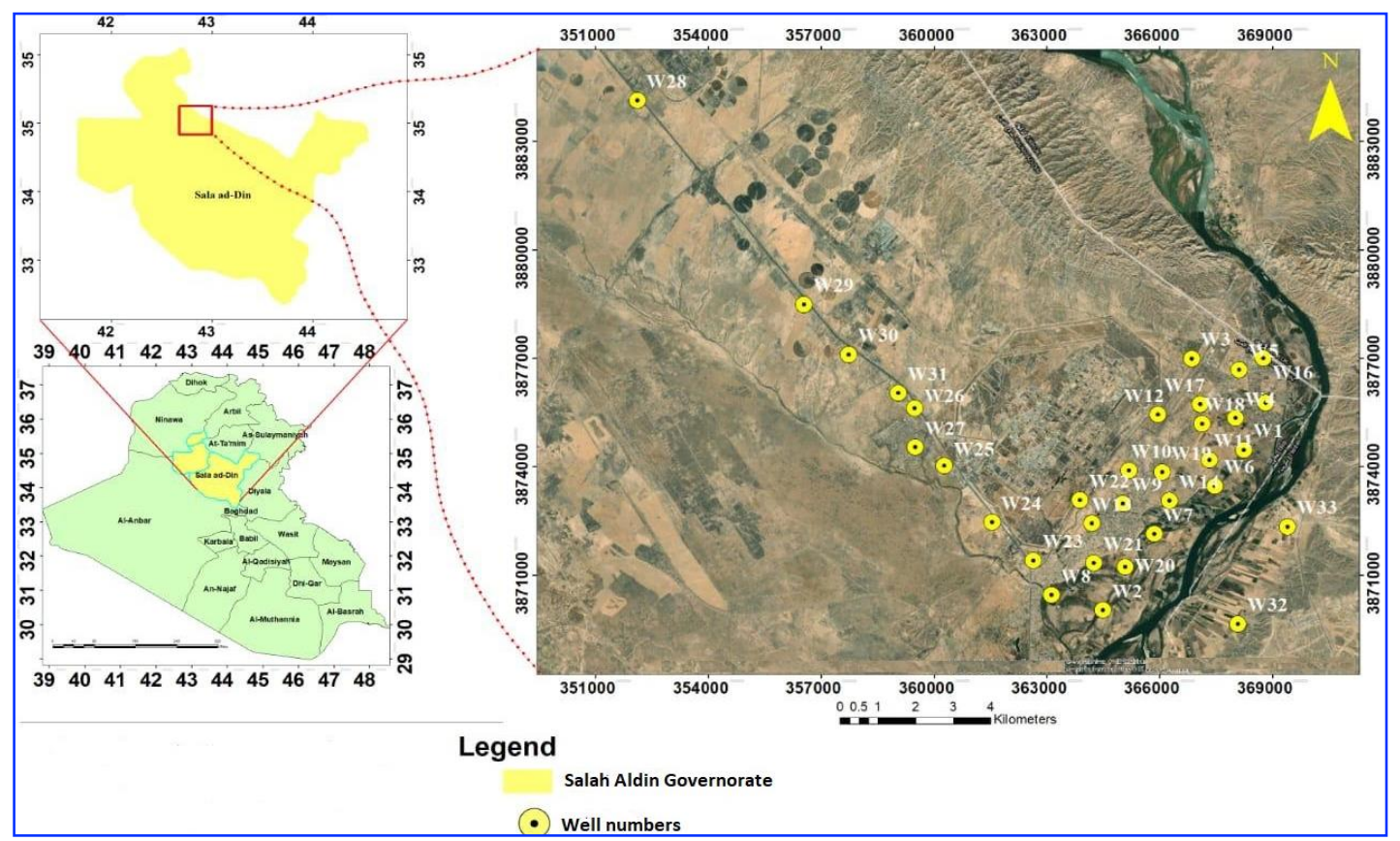

Fig.1. Sampling sites of the groundwater in the study area 


\section{Materials and Methods}

\subsection{Sampling and Analysis}

To assess the groundwater quality of the study area, 33 well water samples were collected in May 2013. Northing and easting coordinates were locating by a portable GPS instrument as in Table 1 and Fig.1.

Table 1. Location and coordinates of studied groundwater samples

\begin{tabular}{clllllll}
\hline $\begin{array}{c}\text { Well } \\
\text { No. }\end{array}$ & Location & Easting & Northing & Well No. & Location & Easting & Northing \\
\hline W1 & Shwaish village & 368255 & 3874477 & W18 & Shwaish village & 367136 & 3875200 \\
W2 & Al-bojwari village & 364502 & 3870045 & W19 & Al-bojwari village & 366070 & 3873853 \\
W3 & Al-hanshi village & 366864 & 3877000 & W20 & Al-bojwari village & 365098 & 3871237 \\
W4 & Shwaish village & 368028 & 3875350 & W21 & Al-bojwari village & 364256 & 3871347 \\
W5 & Al-hanshi village & 368127 & 3876689 & W22 & Al-bojwari village & 363891 & 3873087 \\
W6 & Al-bojwari village & 367478 & 3873474 & W23 & Al-bojwari village & 362650 & 3871417 \\
W7 & Al-bojwari village & 365861 & 3872147 & W24 & Hana Khalil farm & 361547 & 3872471 \\
W8 & Al-bojwari village & 363131 & 3870461 & W25 & Detergents Factory Campus & 360278 & 3874042 \\
W9 & Al-bojwari village & 365028 & 3872987 & W26 & Al-Nesrain fuel station & 359493 & 3875638 \\
W10 & Al-bojwari village & 365198 & 3873907 & W27 & Firas Almuhsin crusher factory & 359507 & 3874551 \\
W11 & Al-bojwari village & 367326 & 3874203 & W28 & Mohammed Alqadori farm & 352114 & 3884144 \\
W12 & Shwaish village & 365966 & 3875450 & W29 & Jazerat Alarab fuel station & 356547 & 3878497 \\
W13 & Al-bojwari village & 364211 & 3872439 & W30 & Al-Baraka block factory & 357736 & 3877112 \\
W14 & Al-bojwari village & 366268 & 3873069 & W31 & Al-Saafi block factory & 359055 & 3876042 \\
W15 & Shwaish village & 368830 & 3875779 & W32 & Al-Laqlaq village & 368085 & 3869665 \\
W16 & Al-hanshi village & 368759 & 3877010 & W33 & Al-Laqlaq village & 369405 & 3872354 \\
W17 & Shwaish village & 367084 & 3875740 & & & & \\
\hline
\end{tabular}

For the chemical analyzes, 1.5-liter polyethylene bottles were used. Each bottle is rinsed with water from the respective well first, and then filled to the bottleneck and stored in a refrigerated box until returning to the laboratory. Physiochemical characteristics of the water samples were analyzed in the laboratories of Tikrit University as in Table 2. The samples of dissolved trace elements are filtered with a $45 \mu \mathrm{m}$ membrane and acidified with concentrated nitric acid to a $\mathrm{pH}$ of less than 2 to maintain trace elements in a dissolved form. After bringing well water samples to the laboratory, they are stored refrigerated at $4{ }^{\circ} \mathrm{C}$ to inhibit microbial activity and avoid any chemical changes (Gautam et al. 2018). Heavy metals ( $\mathrm{Al}, \mathrm{Cd}, \mathrm{Cr}, \mathrm{Cu}, \mathrm{Fe}, \mathrm{Mn}, \mathrm{Ni}, \mathrm{Pb}$ and $\mathrm{Zn}$ ) and metalloids (As, $\mathrm{B}$ and $\mathrm{Se}$ ) were examined by an inductively coupled plasma mass spectrometer device (ICP-MS).

Table 2. Methods Used for the physiochemical analysis

\begin{tabular}{ll}
\hline Parameter & Methods \\
\hline TDS & Gravimetric method \\
$\mathrm{Ca}^{2+}$ and $\mathrm{Mg}^{2+}$ & EDTA titrimetric method \\
$\mathrm{Na}^{+}, \mathrm{K}^{+}$ & Flame photometric method \\
$\mathrm{SO}_{4}^{2-}$ & Turbidimetric method \\
$\mathrm{Cl}^{-}$ & Argentometric method \\
$\mathrm{NO}_{3}^{-}$ & U-V spectrophotometer with wave length 220nm \\
\hline
\end{tabular}

\subsection{Aqueous Geo-Environmental Indices}

\subsubsection{Nemerow Pollution Index (NPI)}

The NPI is a simple mathematical method that determines the contamination of sampling site with various pollutants (Haque et al. 2020). To determine the degree of pollution, the Nemerow Pollution 
Index is applied widely to assess environmental safety (Adamu et al. 2015). To calculate NPI, first the single factor pollution index (Pi) is calculated, then we find the average value of $\mathrm{Pi}$, and finally, uses the average values and the maximum value of Pi in calculating NPI (Zhang et al. 2017) as in the equation below:

$$
\begin{aligned}
& P i=\frac{C i}{S i} \\
& P i_{\text {ave }}=\frac{1}{n} \sum_{i=1}^{n} P i \\
& \mathrm{NPI}=\sqrt{\frac{(\text { Piave })^{2}+\left(\text { Pimax }^{2}\right)^{2}}{2}}
\end{aligned}
$$

Where $P i$ indicates the individual pollution index of the pollutants $i, C i$ is the measured concentration of pollutants $i$; and $S i$ is the standard value according to WHO; $\mathrm{n}$ is the number of pollutants; $P i_{\max }$ is the maximum value of the individual pollution index of the investigated pollutants; and $\mathrm{Pi}_{\text {ave }}$ refers to the mean value of $\mathrm{Pi}$. The Nemerow pollution index is divided into 5 categories, namely clean when NPI $<0.7$; slightly polluted when $0.7 \leq \mathrm{NPI}<1.0$; moderately polluted when $1.0 \leq$ $\mathrm{NPI}<2.0$; heavily polluted when $2.0 \leq \mathrm{NPI}<3.0$; and seriously polluted when NPI $\geq 3.0$ (Reta et al. 2019).

\subsubsection{Synthetic Pollution Index (SPI)}

In order to characterize the pollution degree in surface and ground water and the suitability of this water for drinking, many researchers have been successfully used the SPI (Gautam et al. 2015; Solangi et al. 2018; Egbueri and Unigwe, 2019; Solangi et al. 2019; Hui et al. 2020; Hui et al. 2021). To calculate this indicator, three steps are required, as follows:

- Finding constant of proportionality (K)

$$
\mathrm{K}=\frac{1}{\sum_{i=1}^{n} \mathrm{Si}}
$$

Where $\mathrm{n}$ indicates the number of variables and $\mathrm{Si}$ indicates the standard value for the $\mathrm{i}^{\text {th }}$ variable according to WHO (2017).

- Determining the weight coefficient (Wi)

$$
\mathrm{Wi}=\frac{\mathrm{K}}{\mathrm{Si}}
$$

- Finally, calculating SPI:

$$
\mathrm{SPI}=\sum_{i=1}^{n} \frac{\mathrm{Ci}}{\mathrm{Si}} \times \mathrm{Wi}^{\mathrm{i}}
$$

Where $\mathrm{Ci}$ represents the actual concentration of $\mathrm{i}^{\mathrm{th}}$ parameter.

Depending on the value of SPI, groundwater quality can be divided into 5 categories: SPI $\geq 3.0$ unsuitable for drinking; $1.0 \leq \mathrm{SPI}<3.0$ highly polluted; $0.5 \leq \mathrm{SPI}<1.0$ moderately polluted; $0.2 \leq \mathrm{SPI}$ $<0.5$ slightly polluted; SPI $<0.2$ suitable for drinking (Gautam et al. 2015).

\subsubsection{Pollution Index of Groundwater (PIG)}

This index was proposed by Rao, (2011) and has been applied in many researches as a tool for assessing and monitoring the quality of drinking water (Egbueri and Unigwe, 2019; Olabode et al. 2020; Shukla and Saxena, 2020). For the calculation of pollution index of groundwater, 5 steps are required. The first was to allocate a relative weight ( $\mathrm{Rw}$ ) for each parameter (TDS, $\mathrm{Ca} 2+, \mathrm{Mg} 2+, \mathrm{Na}+, \mathrm{K}+, \mathrm{Cl}-$, SO42- and NO3-). The assigning weight for each parameter is based on its significance and health 
impact. The highest weight (5) was assigned to TDS, SO42- and NO3-, whereas the least one (1) to K+ (Table 3). The second step was to determine weight parameter (Wp) according to equation 7:

$$
\mathrm{Wp}_{\mathrm{i}}=\frac{R w}{\sum R w}
$$

The third step is to calculate the state of concentration $(\mathrm{Sc})$ for every variable by dividing the measured value $(\mathrm{Vm})$ of the parameter by the WHO standard value $(\mathrm{Vs})$ for drinking water. It is calculated as:

$$
\mathrm{Sc}_{\mathrm{i}}=\frac{V m}{V s}
$$

By the fourth step we can calculate the overall groundwater quality $(\mathrm{Ow})$ through multiplying $\mathrm{Wp}$ with Sc as shown in Eq. (9)

$$
\mathrm{Ow}_{\mathrm{i}}=\mathrm{Wp}_{\mathrm{i}} \times \mathrm{Sc}_{\mathrm{i}}
$$

In the last step, the PIG can be evaluated using the following formula:

$$
\mathrm{PIG}=\sum_{i=1}^{n} O w
$$

Depending on PIG value, groundwater quality can be classified into five classes as follow: insignificant pollution when PIG $<1.0$; low pollution when $1.0<\mathrm{PIG}<1.5$; moderate pollution when $1.5<$ PIG $<2.0$; high pollution when $2.0<$ PIG $<2.5$; and very high pollution when PIG $>2.5$ (Rao, 2011).

Table 3. The relative weight $(\mathrm{Rw})$ and weight parameter $\left(\mathrm{W}_{\mathrm{p}}\right)$ of each parameter with the standard values reported by WHO (2017)

\begin{tabular}{llll}
\hline Parameter & Guideline values & Relative weight $(\boldsymbol{R} \boldsymbol{w})$ & Parameter weight $\left(\boldsymbol{W}_{\boldsymbol{p}}\right)$ \\
\hline $\mathrm{TDS}$ & $500 \mathrm{mg} / \mathrm{l}$ & 5 & 0.179 \\
$\mathrm{Ca}$ & $75 \mathrm{mg} / \mathrm{l}$ & 2 & 0.071 \\
$\mathrm{Mg}$ & $30 \mathrm{mg} / \mathrm{l}$ & 2 & 0.071 \\
$\mathrm{Na}$ & $200 \mathrm{mg} / \mathrm{l}$ & 4 & 0.143 \\
$\mathrm{~K}$ & $12 \mathrm{mg} / \mathrm{l}$ & 1 & 0.036 \\
$\mathrm{Cl}$ & $250 \mathrm{mg} / 1$ & 4 & 0.143 \\
$\mathrm{SO}_{4}$ & $250 \mathrm{mg} / \mathrm{l}$ & 5 & 0.179 \\
$\mathrm{NO}_{3}$ & $50 \mathrm{mg} / \mathrm{l}$ & 5 & 0.179 \\
& & $\sum=28$ & $\sum=1.00$ \\
\hline
\end{tabular}

\section{Results and Discussion}

The results of groundwater samples analysis for trace elements are listed in Table 4. The mean concentrations of trace elements were in the order $\mathrm{B}>\mathrm{Mn}>\mathrm{Al}>\mathrm{Zn}>\mathrm{Pb}>\mathrm{Fe}>\mathrm{Cu}>\mathrm{Cr}>\mathrm{Ni}>\mathrm{Cd}>\mathrm{Se}>$ As. The values of $\mathrm{Cd}, \mathrm{Mn}$, and $\mathrm{Pb}$ were higher than the permissible limits (Table 4), which may indicate anthropogenic activities such as the petroleum industry and agriculture in the study area, which affect environmental degradation. The physicochemical parameters are listed in Table 5. They included TDS, $\mathrm{Ca}^{2+}, \mathrm{Mg}^{+}, \mathrm{Na}^{+}, \mathrm{K}^{+}, \mathrm{Cl}^{-}, \mathrm{SO}_{4}{ }^{2-}$ and $\mathrm{NO}_{3}{ }^{-}$, and the mean concentrations of major cation and anion ions were in the order $\mathrm{SO}_{4}{ }^{2-}>\mathrm{Ca}^{2+}>\mathrm{Na}^{+}>\mathrm{Cl}^{-}>\mathrm{Mg}^{2+}>\mathrm{NO}_{3}{ }^{-}>\mathrm{K}^{+}$. 
Table 4. Concentrations of the trace elements in $\mu \mathrm{g} / 1$ in groundwater and their comparison with WHO (2017)

\begin{tabular}{|c|c|c|c|c|c|c|c|c|c|c|c|c|}
\hline Well No. & Al & Cd & $\mathrm{Cr}$ & $\mathrm{Cu}$ & $\mathbf{F e}$ & Mn & $\mathbf{N i}$ & $\mathbf{P b}$ & $\mathbf{Z n}$ & As & B & $\mathrm{Se}$ \\
\hline W1 & 87 & 2.6 & 12.3 & 11.7 & 33 & 600.3 & 4.8 & 31.8 & 77.1 & 3 & 1443 & 4.5 \\
\hline W2 & 45 & 1.3 & 12.6 & 9.6 & 30 & 11.5 & 5.1 & 15.9 & 62.7 & 1.5 & 2184 & 6.3 \\
\hline W3 & 354 & 29.0 & 9.6 & 13.2 & 126 & 25.2 & 12.9 & 57.9 & 138.6 & 1.8 & 93 & 6.9 \\
\hline W4 & 42 & 1.3 & 4.5 & 5.1 & 39 & 2618.6 & 12.9 & 20.7 & 120.6 & 3 & 264 & 8.4 \\
\hline W5 & 51 & 1.8 & 15.6 & 8.4 & 30 & 11.6 & 5.1 & 24.3 & 70.2 & 1.5 & 1200 & 5.7 \\
\hline W6 & 36 & 11.2 & 6.6 & 8.1 & 30 & 149.8 & 5.7 & 19.5 & 112.2 & 2.7 & 1194 & 6.3 \\
\hline W7 & 69 & 6.2 & 12.6 & 9.6 & 33 & 8.1 & 6.9 & 39.9 & 88.5 & 2.1 & 618 & 5.7 \\
\hline W8 & 99 & 4.2 & 9.6 & 9.6 & 33 & 7.7 & 6 & 35.1 & 81.6 & 2.4 & 612 & 8.4 \\
\hline W9 & 63 & 6.4 & 16.5 & 39.6 & 30 & 7.8 & 3.3 & 143.7 & 101.4 & 1.5 & 564 & 7.8 \\
\hline W10 & 291 & 4.7 & 14.7 & 18.9 & 33 & 65.0 & 9.3 & 56.4 & 89.1 & 1.8 & 1965 & 5.4 \\
\hline W11 & 123 & 22.7 & 9.9 & 17.4 & 57 & 921.4 & 10.8 & 42.6 & 76.8 & 2.7 & 999 & 5.1 \\
\hline W12 & 66 & 2.5 & 11.7 & 12.9 & 51 & 40.0 & 8.7 & 37.8 & 72.6 & 1.5 & 501 & 4.5 \\
\hline W13 & 186 & 2.2 & 15.3 & 14.4 & 36 & 11.3 & 9.3 & 35.7 & 76.8 & 1.8 & 651 & 6.3 \\
\hline W14 & 105 & 14.7 & 21.6 & 13.8 & 63 & 105.4 & 12.6 & 29.4 & 91.8 & 2.4 & 1587 & 6.3 \\
\hline W15 & 63 & 3.0 & 14.1 & 11.7 & 33 & 805.5 & 5.4 & 47.1 & 79.2 & 2.7 & 291 & 5.7 \\
\hline W16 & 57 & 6.9 & 15.3 & 9.9 & 30 & 35.2 & 12.3 & 165.6 & 85.2 & 1.5 & 2748 & 6.9 \\
\hline W17 & 81 & 2.4 & 13.5 & 12.3 & 30 & 1337.8 & 6.3 & 26.4 & 99.3 & 1.5 & 1476 & 5.1 \\
\hline W18 & 39 & 2.7 & 12.3 & 11.7 & 39 & 1100.1 & 5.7 & 94.8 & 83.4 & 1.5 & 1344 & 6.3 \\
\hline W19 & 75 & 5.8 & 17.1 & 31.2 & 30 & 13.9 & 4.8 & 118.2 & 94.8 & 1.5 & 588 & 7.5 \\
\hline W20 & 57 & 25.0 & 15.6 & 23.1 & 30 & 76.3 & 9 & 63.9 & 79.2 & 1.5 & 2100 & 5.7 \\
\hline W21 & 63 & 4.4 & 12.3 & 18.3 & 60 & 51.7 & 9 & 53.7 & 70.5 & 2.7 & 1710 & 4.8 \\
\hline W22 & 138 & 13.7 & 14.4 & 11.1 & 93 & 205.3 & 12.6 & 99.9 & 59.1 & 2.4 & 663 & 11.1 \\
\hline W23 & 81 & 6.7 & 9.6 & 11.7 & 33 & 10.4 & 8.4 & 68.1 & 58.8 & 1.8 & 1428 & 4.5 \\
\hline W24 & 48 & 2.3 & 15 & 19.8 & 39 & 145.7 & 8.4 & 22.2 & 70.2 & 1.5 & 1131 & 5.7 \\
\hline W25 & 45 & 15.8 & 12.6 & 34.8 & 33 & 18.5 & 5.1 & 26.4 & 58.5 & 1.5 & 1410 & 4.8 \\
\hline W26 & 99 & 7.4 & 9.9 & 14.4 & 36 & 64.1 & 8.7 & 47.7 & 92.1 & 2.1 & 1530 & 3.6 \\
\hline W27 & 48 & 2.8 & 7.8 & 9.6 & 51 & 7.4 & 6 & 59.7 & 61.5 & 1.5 & 1767 & 2.1 \\
\hline W28 & 81 & 5.2 & 6.6 & 7.8 & 30 & 8.8 & 5.4 & 37.2 & 77.4 & 1.5 & 1263 & 3.6 \\
\hline W29 & 93 & 1.2 & 13.8 & 23.7 & 45 & 9.4 & 6 & 41.1 & 59.1 & 1.5 & 534 & 1.8 \\
\hline W30 & 69 & 6.3 & 12.3 & 9.9 & 33 & 9.3 & 6.3 & 39.6 & 61.5 & 1.5 & 633 & 3.3 \\
\hline W31 & 36 & 1.4 & 9.3 & 8.7 & 30 & 88.0 & 5.7 & 35.1 & 64.2 & 1.5 & 1173 & 4.2 \\
\hline W32 & 45 & 4.4 & 13.8 & 15.9 & 36 & 19.3 & 7.2 & 81.6 & 109.8 & 1.5 & 621 & 2.7 \\
\hline W33 & 39 & 5.1 & 12.6 & 18.3 & 33 & 17.4 & 9 & 53.4 & 89.1 & 1.5 & 483 & 5.1 \\
\hline Ave. & 87 & 7.0 & 12.5 & 15 & 42 & 260.8 & 7.7 & 53.7 & 81.7 & 1.9 & 1034 & 5.5 \\
\hline $\begin{array}{c}\text { WHO, } \\
2017\end{array}$ & 200 & 3 & 50 & 2000 & 300 & 400 & 70 & 10 & 3000 & 10 & 2400 & 40 \\
\hline
\end{tabular}

\subsection{Groundwater Quality Assessment Using NPI}

To evaluate the quality of groundwater in the study area, a Nemerow pollution index was used to calculate the twelve metals and semi-metals. The NPI values were listed in Table 6, and all sampling stations had values of NPI exceeded 1, indicating the contamination of the wells by trace elements (Zhang et al. 2017). The NPI values are ranged from 1.14 at well 2 to 6.89 at well 3 (Table 6). The results of NPI values indicate that $58 \%$ of the wells are considered seriously polluted, $33 \%$ are heavily polluted and $9 \%$ are moderately polluted by trace elements. According to those values, the waters are considered unsuitable for drinking (Mishra et al., 2021). The high concentrations of cadmium, lead and manganese compared to the standards of the World Health Organization had a clear effect on the high values of the Nemerow pollution index in many sites (Table 6). 
Table 5. Concentrations values of physiochemical parameters $(\mathrm{mg} / \mathrm{l})$ in groundwater

\begin{tabular}{|c|c|c|c|c|c|c|c|c|}
\hline Well no. & TDS & $\mathrm{Ca}^{2+}$ & $\mathrm{Mg}^{2+}$ & $\mathrm{Na}^{+}$ & $\overline{\mathbf{K}^{+}}$ & $\mathrm{Cl}^{-}$ & $\overline{\mathrm{SO}_{4}{ }^{2-}}$ & $\mathrm{NO}_{3}^{-}$ \\
\hline W1 & 1980 & 299.00 & 107.80 & 163.70 & 5.66 & 332 & 1020 & 12.1 \\
\hline W2 & 1990 & 168.67 & 56.35 & 377.60 & 5.80 & 85 & 1267 & 10.8 \\
\hline W3 & 1050 & 156.27 & 43.29 & 116.07 & 2.79 & 93 & 576 & 10.8 \\
\hline W4 & 2400 & 270.03 & 92.97 & 368.94 & 4.47 & 270 & 1358 & 13.6 \\
\hline W5 & 2425 & 378.09 & 147.48 & 197.16 & 4.80 & 75 & 1571 & 9.9 \\
\hline W6 & 2075 & 394.02 & 87.51 & 117.63 & 2.16 & 63 & 1355 & 10.5 \\
\hline W7 & 2250 & 241.35 & 106.05 & 357.75 & 3.18 & 438 & 1035 & 8.7 \\
\hline W8 & 2150 & 375.51 & 100.29 & 181.35 & 2.79 & 192 & 1269 & 9.3 \\
\hline W9 & 2500 & 266.00 & 111.77 & 374.00 & 5.21 & 198 & 1501 & 10.3 \\
\hline W10 & 2770 & 311.00 & 199.00 & 299.00 & 5.61 & 511 & 1400 & 11.9 \\
\hline W11 & 2190 & 245.00 & 105.00 & 331.44 & 9.33 & 350 & 1100 & 10.5 \\
\hline W12 & 1875 & 278.60 & 89.35 & 205.70 & 11.00 & 160 & 1080 & 15.7 \\
\hline W13 & 2150 & 208.00 & 78.64 & 356.00 & 4.35 & 145 & 1300 & 7.2 \\
\hline W14 & 3200 & 411.26 & 137.60 & 381.00 & 3.44 & 206 & 2016 & 10.9 \\
\hline W15 & 1410 & 199.00 & 57.25 & 157.00 & 8.00 & 99 & 867 & 9.3 \\
\hline W16 & 1188 & 145.00 & 67.00 & 115.00 & 9.70 & 98 & 687 & 11.2 \\
\hline W17 & 2330 & 315.33 & 145.83 & 198.40 & 7.60 & 115 & 1519 & 14.8 \\
\hline W18 & 2600 & 287.00 & 177.00 & 355.00 & 4.70 & 499 & 1220 & 10.3 \\
\hline W19 & 2230 & 300.00 & 160.70 & 231.30 & 6.10 & 295 & 1196 & 12.3 \\
\hline W20 & 1885 & 301.45 & 94.83 & 198.00 & 8.60 & 355 & 900.8 & 11.2 \\
\hline W21 & 2220 & 243.70 & 109.30 & 367.63 & 4.30 & 341 & 1124 & 17.2 \\
\hline W22 & 2340 & 367.00 & 97.20 & 298.00 & 2.60 & 481 & 1050 & 10.2 \\
\hline W23 & 2200 & 301.00 & 125.44 & 233.76 & 4.6 & 368 & 1113 & 9.6 \\
\hline W24 & 3680 & 355.05 & 209.25 & 500.10 & 4.68 & 231 & 2313 & 11.8 \\
\hline W25 & 1975 & 196.23 & 99.30 & 290.00 & 2.9 & 246 & 1112 & 9.3 \\
\hline W26 & 3100 & 356.25 & 154.98 & 361.56 & 4.05 & 198 & 1941 & 10.7 \\
\hline W27 & 3220 & 390.00 & 201.00 & 456.93 & 4.72 & 556 & 1562 & 10.1 \\
\hline W28 & 2050 & 288.60 & 127.85 & 202.60 & 9.3 & 255 & 1131 & 19.3 \\
\hline W29 & 2390 & 220.33 & 103.67 & 391.00 & 7.55 & 165 & 1450 & 8.3 \\
\hline W30 & 3110 & 433.00 & 144.00 & 399.60 & 5.83 & 634 & 1450 & 10.9 \\
\hline W31 & 2455 & 297.00 & 120.43 & 320.00 & 3.2 & 122 & 1565 & 10.3 \\
\hline W32 & 1245 & 177.25 & 61.52 & 129.44 & 4.92 & 107 & 741 & 11.5 \\
\hline W33 & 2200 & 323.66 & 134.65 & 178.63 & 2.88 & 173 & 1346 & 15.4 \\
\hline average & 2267.6 & 287.87 & 116.80 & 279.13 & 5.36 & 256.32 & 1276.87 & 11.39 \\
\hline
\end{tabular}


Table 6. Values of the individual pollution index $(\mathrm{Pi})$ of the pollutants and Nemerow pollution index (NPI)

\begin{tabular}{|c|c|c|c|c|c|c|c|c|c|c|c|c|c|c|}
\hline Well No. & $\begin{array}{c}\mathbf{P i} \\
\text { (Al) }\end{array}$ & $\begin{array}{c}\mathbf{P i} \\
(\mathbf{C d})\end{array}$ & $\begin{array}{c}\mathbf{P i} \\
(\mathbf{C r})\end{array}$ & $\begin{array}{c}\mathbf{P i} \\
(\mathbf{C u})\end{array}$ & $\begin{array}{c}\mathbf{P i} \\
(\mathbf{F e})\end{array}$ & $\begin{array}{c}\mathbf{P i} \\
(\mathbf{M n})\end{array}$ & $\begin{array}{c}\mathbf{P i} \\
(\mathbf{N i})\end{array}$ & $\begin{array}{c}\mathbf{P i} \\
(\mathbf{P b})\end{array}$ & $\begin{array}{c}\mathbf{P i} \\
(\mathbf{Z n})\end{array}$ & $\begin{array}{c}\mathbf{P i} \\
(\mathbf{A s})\end{array}$ & $\begin{array}{c}\mathbf{P i} \\
(\mathbf{B})\end{array}$ & $\begin{array}{c}\mathbf{P i} \\
(\mathbf{S e})\end{array}$ & $\begin{array}{c}\mathbf{P i} \\
\text { ave }\end{array}$ & NPI \\
\hline W1 & 0.44 & 0.87 & 0.25 & 0.006 & 0.17 & 1.50 & 0.07 & 3.18 & 0.03 & 0.3 & 0.60 & 0.11 & 0.50 & 2.28 \\
\hline W2 & 0.23 & 0.43 & 0.25 & 0.005 & 0.15 & 0.03 & 0.07 & 1.59 & 0.02 & 0.15 & 0.91 & 0.16 & 0.27 & 1.14 \\
\hline W3 & 1.77 & 9.67 & 0.19 & 0.007 & 0.63 & 0.06 & 0.18 & 5.79 & 0.05 & 0.18 & 0.04 & 0.17 & 1.25 & 6.89 \\
\hline W4 & 0.21 & 0.43 & 0.09 & 0.003 & 0.20 & 6.55 & 0.18 & 2.07 & 0.04 & 0.3 & 0.11 & 0.21 & 0.69 & 4.65 \\
\hline W5 & 0.26 & 0.60 & 0.31 & 0.004 & 0.15 & 0.03 & 0.07 & 2.43 & 0.02 & 0.15 & 0.50 & 0.14 & 0.31 & 1.73 \\
\hline W6 & 0.18 & 3.73 & 0.13 & 0.004 & 0.15 & 0.37 & 0.08 & 1.95 & 0.04 & 0.27 & 0.50 & 0.16 & 0.50 & 2.66 \\
\hline W7 & 0.35 & 2.07 & 0.25 & 0.005 & 0.17 & 0.02 & 0.10 & 3.99 & 0.03 & 0.21 & 0.26 & 0.14 & 0.51 & 2.84 \\
\hline W8 & 0.50 & 1.40 & 0.19 & 0.005 & 0.17 & 0.02 & 0.09 & 3.51 & 0.03 & 0.24 & 0.26 & 0.21 & 0.44 & 2.50 \\
\hline W9 & 0.32 & 2.13 & 0.33 & 0.020 & 0.15 & 0.02 & 0.05 & 14.37 & 0.03 & 0.15 & 0.24 & 0.20 & 1.20 & 10.20 \\
\hline W10 & 1.46 & 1.57 & 0.29 & 0.009 & 0.17 & 0.16 & 0.13 & 5.64 & 0.03 & 0.18 & 0.82 & 0.14 & 0.71 & 4.02 \\
\hline W11 & 0.62 & 7.57 & 0.20 & 0.009 & 0.29 & 2.30 & 0.15 & 4.26 & 0.03 & 0.27 & 0.42 & 0.13 & 1.08 & 5.40 \\
\hline W12 & 0.33 & 0.83 & 0.23 & 0.006 & 0.26 & 0.10 & 0.12 & 3.78 & 0.02 & 0.15 & 0.21 & 0.11 & 0.41 & 2.69 \\
\hline W13 & 0.93 & 0.73 & 0.31 & 0.007 & 0.18 & 0.03 & 0.13 & 3.57 & 0.03 & 0.18 & 0.27 & 0.16 & 0.43 & 2.54 \\
\hline W14 & 0.53 & 4.90 & 0.43 & 0.007 & 0.32 & 0.26 & 0.18 & 2.94 & 0.03 & 0.24 & 0.66 & 0.16 & 0.71 & 3.50 \\
\hline W15 & 0.32 & 1.00 & 0.28 & 0.006 & 0.17 & 2.01 & 0.08 & 4.71 & 0.03 & 0.27 & 0.12 & 0.14 & 0.61 & 3.36 \\
\hline W16 & 0.29 & 2.30 & 0.31 & 0.005 & 0.15 & 0.09 & 0.18 & 16.56 & 0.03 & 0.15 & 1.15 & 0.17 & 1.42 & 11.75 \\
\hline W17 & 0.41 & 0.80 & 0.27 & 0.006 & 0.15 & 3.34 & 0.09 & 2.64 & 0.03 & 0.15 & 0.62 & 0.13 & 0.58 & 2.40 \\
\hline W18 & 0.20 & 0.90 & 0.25 & 0.006 & 0.20 & 2.75 & 0.08 & 9.48 & 0.03 & 0.15 & 0.56 & 0.16 & 0.98 & 6.74 \\
\hline W19 & 0.38 & 1.93 & 0.34 & 0.016 & 0.15 & 0.03 & 0.07 & 11.82 & 0.03 & 0.15 & 0.25 & 0.19 & 1.02 & 8.39 \\
\hline W20 & 0.29 & 8.33 & 0.31 & 0.012 & 0.15 & 0.19 & 0.13 & 6.39 & 0.03 & 0.15 & 0.88 & 0.14 & 1.13 & 5.95 \\
\hline W21 & 0.32 & 1.47 & 0.25 & 0.009 & 0.30 & 0.13 & 0.13 & 5.37 & 0.02 & 0.27 & 0.71 & 0.12 & 0.61 & 3.82 \\
\hline W22 & 0.69 & 4.57 & 0.29 & 0.006 & 0.47 & 0.51 & 0.18 & 9.99 & 0.02 & 0.24 & 0.28 & 0.28 & 1.17 & 7.11 \\
\hline W23 & 0.41 & 2.23 & 0.19 & 0.006 & 0.17 & 0.03 & 0.12 & 6.81 & 0.02 & 0.18 & 0.60 & 0.11 & 0.72 & 4.84 \\
\hline W24 & 0.24 & 0.77 & 0.30 & 0.010 & 0.20 & 0.36 & 0.12 & 2.22 & 0.02 & 0.15 & 0.47 & 0.14 & 0.33 & 1.59 \\
\hline W25 & 0.23 & 5.27 & 0.25 & 0.017 & 0.17 & 0.05 & 0.07 & 2.64 & 0.02 & 0.15 & 0.59 & 0.12 & 0.64 & 3.75 \\
\hline W26 & 0.50 & 2.47 & 0.20 & 0.007 & 0.18 & 0.16 & 0.12 & 4.77 & 0.03 & 0.21 & 0.64 & 0.09 & 0.62 & 3.40 \\
\hline W27 & 0.24 & 0.93 & 0.16 & 0.005 & 0.26 & 0.02 & 0.09 & 5.97 & 0.02 & 0.15 & 0.74 & 0.05 & 0.57 & 4.24 \\
\hline W28 & 0.41 & 1.73 & 0.13 & 0.004 & 0.15 & 0.02 & 0.08 & 3.72 & 0.03 & 0.15 & 0.53 & 0.09 & 0.47 & 2.65 \\
\hline W29 & 0.47 & 0.40 & 0.28 & 0.012 & 0.23 & 0.02 & 0.09 & 4.11 & 0.02 & 0.15 & 0.22 & 0.05 & 0.40 & 2.92 \\
\hline W30 & 0.35 & 2.10 & 0.25 & 0.005 & 0.17 & 0.02 & 0.09 & 3.96 & 0.02 & 0.15 & 0.26 & 0.08 & 0.50 & 2.82 \\
\hline W31 & 0.18 & 0.47 & 0.19 & 0.004 & 0.15 & 0.22 & 0.08 & 3.51 & 0.02 & 0.15 & 0.49 & 0.11 & 0.37 & 2.50 \\
\hline W32 & 0.23 & 1.47 & 0.28 & 0.008 & 0.18 & 0.05 & 0.10 & 8.16 & 0.04 & 0.15 & 0.26 & 0.07 & 0.73 & 5.79 \\
\hline W33 & 0.20 & 1.70 & 0.25 & 0.009 & 0.17 & 0.04 & 0.13 & 5.34 & 0.03 & 0.15 & 0.20 & 0.13 & 0.56 & 3.80 \\
\hline
\end{tabular}

\subsection{Groundwater Quality Assessment Using SPI}

The SPI is another tool which can be used to determine the groundwater quality via merge the influence of different pollutants. The Synthetic pollution index values of groundwater samples are ranged from 0.56 at well 2 to 6.38 at well 3 (Table 7). The SPI values showed that $21 \%$ of wells are moderately polluted, $52 \%$ are highly polluted, and $27 \%$ are unsuitable for drinking (Table 7). From calculating the values of the two indices (NPI and SPI), we find that many values are identical spatially in terms of the degree of groundwater pollution and their unsuitability for drinking (Tables 6 and 7).

\subsection{Groundwater Quality Assessment Using PIG}

The PIG is a reliable index for evaluating groundwater wells in the study area. Physicochemical variables were used to calculate this index. The calculated values of the pollution index of groundwater are ranged from 1.22 to 4.35 (Table 7). Depending on the rating of PIG values, 9\%, 3\%, 21\% and 67\% of the groundwater samples fall under low, moderate, high, and very high pollution categories, respectively. This value $(\mathrm{Ow})$ considered as a contributor of each parameter to groundwater pollution. Therefore, the greater value Ow refer to the greater its contribution. From Table 7, it is clear that TDS and sulfate ions have the greatest effect on the value of Ow, and thus these two parameters had the 
largest contributors among other ions in groundwater pollution. In contrast, nitrate and potassium ions have the least contribution to pollution.

Table 7. Values of Ow, PIG and SPI of the groundwater samples

\begin{tabular}{|c|c|c|c|c|c|c|c|c|c|c|}
\hline Well No. & $\begin{array}{c}\text { Ow } \\
\text { TDS }\end{array}$ & $\begin{array}{c}\mathbf{O w} \\
\mathrm{Ca}^{2+}\end{array}$ & $\begin{array}{c}\mathbf{O w} \\
\mathrm{Mg}^{2+}\end{array}$ & $\begin{array}{c}\mathbf{O w} \\
\mathrm{Na}^{+}\end{array}$ & Ow $\mathbf{K}^{+}$ & Ow Cl${ }^{-}$ & $\begin{array}{c}\mathrm{OW} \\
\mathrm{SO}_{4}{ }^{2-}\end{array}$ & $\begin{array}{c}\mathrm{Ow} \\
\mathrm{NO}_{3}^{-}\end{array}$ & PIG & SPI \\
\hline W1 & 0.71 & 0.28 & 0.26 & 0.12 & 0.02 & 0.19 & 0.73 & 0.04 & 2.34 & 1.09 \\
\hline W2 & 0.71 & 0.16 & 0.13 & 0.27 & 0.02 & 0.05 & 0.91 & 0.04 & 2.29 & 0.56 \\
\hline W3 & 0.38 & 0.15 & 0.10 & 0.08 & 0.01 & 0.05 & 0.41 & 0.04 & 1.22 & 6.38 \\
\hline W4 & 0.86 & 0.26 & 0.22 & 0.26 & 0.01 & 0.15 & 0.97 & 0.05 & 2.79 & 0.70 \\
\hline W5 & 0.87 & 0.36 & 0.35 & 0.14 & 0.01 & 0.04 & 1.12 & 0.04 & 2.93 & 0.79 \\
\hline W6 & 0.74 & 0.37 & 0.21 & 0.08 & 0.01 & 0.04 & 0.97 & 0.04 & 2.46 & 2.45 \\
\hline W7 & 0.81 & 0.23 & 0.25 & 0.26 & 0.01 & 0.25 & 0.74 & 0.03 & 2.57 & 1.87 \\
\hline W8 & 0.77 & 0.36 & 0.24 & 0.13 & 0.01 & 0.11 & 0.91 & 0.03 & 2.55 & 1.43 \\
\hline W9 & 0.90 & 0.25 & 0.26 & 0.27 & 0.02 & 0.11 & 1.07 & 0.04 & 2.92 & 3.61 \\
\hline W10 & 0.99 & 0.29 & 0.47 & 0.21 & 0.02 & 0.29 & 1.00 & 0.04 & 3.32 & 1.88 \\
\hline W11 & 0.78 & 0.23 & 0.25 & 0.24 & 0.03 & 0.20 & 0.79 & 0.04 & 2.55 & 4.97 \\
\hline W12 & 0.67 & 0.26 & 0.21 & 0.15 & 0.03 & 0.09 & 0.77 & 0.06 & 2.25 & 1.15 \\
\hline W13 & 0.77 & 0.20 & 0.19 & 0.25 & 0.01 & 0.08 & 0.93 & 0.03 & 2.46 & 1.07 \\
\hline W14 & 1.15 & 0.39 & 0.33 & 0.27 & 0.01 & 0.12 & 1.44 & 0.04 & 3.74 & 3.29 \\
\hline W15 & 0.50 & 0.19 & 0.14 & 0.11 & 0.02 & 0.06 & 0.62 & 0.03 & 1.68 & 1.42 \\
\hline W16 & 0.43 & 0.14 & 0.16 & 0.08 & 0.03 & 0.06 & 0.49 & 0.04 & 1.42 & 4.08 \\
\hline W17 & 0.83 & 0.30 & 0.35 & 0.14 & 0.02 & 0.07 & 1.09 & 0.05 & 2.85 & 0.95 \\
\hline W18 & 0.93 & 0.27 & 0.42 & 0.25 & 0.01 & 0.29 & 0.87 & 0.04 & 3.09 & 2.13 \\
\hline W19 & 0.80 & 0.28 & 0.38 & 0.17 & 0.02 & 0.17 & 0.86 & 0.04 & 2.72 & 3.08 \\
\hline W20 & 0.67 & 0.29 & 0.22 & 0.14 & 0.03 & 0.20 & 0.64 & 0.04 & 2.24 & 5.72 \\
\hline W21 & 0.79 & 0.23 & 0.26 & 0.26 & 0.01 & 0.20 & 0.80 & 0.06 & 2.62 & 1.78 \\
\hline W22 & 0.84 & 0.35 & 0.23 & 0.21 & 0.01 & 0.28 & 0.75 & 0.04 & 2.70 & 4.27 \\
\hline W23 & 0.79 & 0.28 & 0.30 & 0.17 & 0.01 & 0.21 & 0.80 & 0.03 & 2.59 & 2.42 \\
\hline W24 & 1.32 & 0.34 & 0.50 & 0.36 & 0.01 & 0.13 & 1.66 & 0.04 & 4.35 & 0.86 \\
\hline W25 & 0.71 & 0.19 & 0.24 & 0.21 & 0.01 & 0.14 & 0.80 & 0.03 & 2.31 & 3.39 \\
\hline W26 & 1.11 & 0.34 & 0.37 & 0.26 & 0.01 & 0.11 & 1.39 & 0.04 & 3.63 & 2.22 \\
\hline W27 & 1.15 & 0.37 & 0.48 & 0.33 & 0.01 & 0.32 & 1.12 & 0.04 & 3.81 & 1.55 \\
\hline W28 & 0.73 & 0.27 & 0.30 & 0.14 & 0.03 & 0.15 & 0.81 & 0.07 & 2.51 & 1.62 \\
\hline W29 & 0.86 & 0.21 & 0.25 & 0.28 & 0.02 & 0.09 & 1.04 & 0.03 & 2.77 & 0.96 \\
\hline W30 & 1.11 & 0.41 & 0.34 & 0.29 & 0.02 & 0.36 & 1.04 & 0.04 & 3.61 & 1.87 \\
\hline W31 & 0.88 & 0.28 & 0.29 & 0.23 & 0.01 & 0.07 & 1.12 & 0.04 & 2.91 & 0.89 \\
\hline W32 & 0.45 & 0.17 & 0.15 & 0.09 & 0.01 & 0.06 & 0.53 & 0.04 & 1.50 & 2.22 \\
\hline W33 & 0.79 & 0.31 & 0.32 & 0.13 & 0.01 & 0.10 & 0.96 & 0.06 & 2.67 & 1.88 \\
\hline
\end{tabular}

\section{Conclusions}

A groundwater quality assessment to the north of Salah Al-Din governorate using Nemerow pollution index, synthetic pollution index, and pollution index of groundwater was carried out. Metals and metalloids (Al, Cd, Cr, Cu, Fe, Mn, Ni, Pb, Zn, As, B and Se) were used in the calculation of both NPI and SPI, while in the calculation of GIP, physicochemical parameters (TDS, $\mathrm{Ca}^{2+}, \mathrm{Mg}^{2+}, \mathrm{Na}^{+}, \mathrm{K}^{+}$, $\mathrm{Cl}^{-}, \mathrm{SO}_{4}{ }^{2-}$ and $\mathrm{NO}_{3}{ }^{-}$) were used. According to NPI values, all groundwater samples are unsuitable for drinking. Similarly, SPI values are also indicating pollution of the groundwater by trace elements. As for the PIG, the total dissolved solids and sulfate ions showed a direct effect on the groundwater quality among other physicochemical parameters. 


\section{Acknowledgements}

The authors would like to thank the Head of the Department of Applied Geology Prof. Dr. Mohammad Rashed Abood at the Tikrit University for providing us the required facilities in this study. The authors are very grateful to the reviewers, Editor in Chief Prof. Dr. Salih M. Awadh, the Secretary of Journal Mr. Samir R. Hijab, and the Technical Editors for their great efforts and valuable comments.

\section{References}

Abd El- Hamid, H. T., Hegazy, T.A., 2017. Evaluation of water quality pollution indices for groundwater resources of New Damietta, Egypt. MOJ Ecology \& Environmental Science, 2(6), 263- 266.

Adamu, C.I., Nganje, T.N., Edet, A., 2015. Heavy metal contamination and health risk assessment associated with abandoned barite mines in Cross River State, southeastern Nigeria. Environmental Nanotechnology, Monitoring \& Management, 3(1), 10-21.

AL-Adhmawee R.M.J., 2013. Effect of Variation of Sedimentological and Textural Facies on the Hydraulic Properties of Unconfined Aquifer, Baiji city, North Iraq. M.Sc. Thesis, Department of Applied Geology, Tikrit University, Iraq.

Al-Hwez A.T.A.A., 2014. Bathometric Study for Cross Section on Tigris River at Water Intake Stations and Evaluation of Sediments at the Basins/ Baiji City. M.Sc. Thesis, Department of Applied Geology, College of Science, Tikrit University, Iraq.

Al-Kubaisi, Q.Y and Al-Sumaidai, S.K., 2021. Hydrochemical evaluation of groundwater in Al-Khasfa Area within Haditha, Western Iraq. Iraqi Geological Journal, 54(2A), 103-111.

Al-Maiyahy, D.S., 2004. Tectonic and structure of Anticline (Himreen - Makhul) North-East Iraq. M.Sc. Thesis. Geology Department, Basra University, Iraq.

Al-Salmani, S.S.M.N., 2013. Hydrogeological conditions of Injana Aquifers for Western Makhul Area, North Iraq. M.Sc. Thesis, Department of Applied Geology, Tikrit University, Iraq.

Awadh, M.S., Al-Kilabi, J.A., Abdulhussein, F.M., 2016. Assessment of groundwater quality using water quality index in, Al-Hawija area, northern Iraq. Iraqi Geological Journal. 39-49(1), 67-76.

Beg, A.A.F., Awadh, S.M., Thamer, M.B., Al-Sulttani, A.H., 2021. Assessment of groundwater quality for drinking purposes using water quality index, and identifying the affecting mechanism in Rashdiya, Central Iraq. Iraqi Geological Journal. 54 (1F), 20-32.

Egbueri, J.C., Unigwe, C.O., 2019. An integrated indexical investigation of selected heavy metals in drinking water resources from a coastal plain aquifer in Nigeria. SN Applied Sciences, 1(11), 1-10.

Gautam, S.K., Evangelos, T., Singh, S.K., Tripathi, J.K., Singh, A.K., 2018. Environmental monitoring of water resources with the use of PoS index: a case study from Subarnarekha River basin, Indi. Environmental Earth Sciences, 77(3), 1-17.

Gautam, S.K., Maharana, C., Sharma, D., Singh, A.K., Tripathi, J.K., Singh, S.K., 2015. Evaluation of groundwater quality in the Chotanagpur Plateau region of the Subarnarekha River Basin, Jharkhand State, India. Sustainability of Water Quality and Ecology, 6(1), 57-74 .

Gharaat, M.J., Mohammadi, Z., Rezanezhad F., 2020. Distribution and origin of potentially toxic elements in a multi-aquifer system. Environmental Science and Pollution Research, 27(35), $43724-43742$.

Haque, M.M., Niloy, N.M., Nayna, O.K., Fatema, K.J., Quraishi, S.B., Park, J.H., Kim, K.W., Tareq, S.M., 2020. Variability of water quality and metal pollution index in the Ganges River, Bangladesh. Environmental Science and Pollution Research, 27(34), 42582-42599.

Hui, T., Jizhong, D., Qifa, S., Yan, G., Zhuang, K.M., Hongtao, J., 2020. Evaluation of shallow groundwater for drinking purpose based on water quality index and synthetic pollution index in Changchun New District, China. Environmental Forensics, 22(1-2), 189-204 .

Hui, T., Xiujuan, L., Qifa, S., Qiang, L., Zhuang, K., Yan, G., 2021 Evaluation of Drinking Water Quality Using The Water Quality Index (WQI), the Synthetic Pollution Index (SPI) and geospatial tools in Lianhuashan District, China. Pollution Journal Environment Studies, 30(1), 141-153.

Jassim S.Z. and Goff G.C., 2006. Geology of Iraq. Published by Dolin, Prague and Moravian Museum, Brno. 345 pp. 
Mishra, S., Kumar, A., Shukla, P., 2021. Estimation of heavy metal contamination in the Hindon River, India: an environmetric approach. Applied Water Science, 11(1), 1-9.

Nasrabadi, T., 2015. An index approach to metallic pollution in river waters. International Journal of Environment Resources, 9(1), 385-394.

Olabode, O.F., Ajala, T.F., Asowata, T.I., 2020. An assessment of the potential health risks associated with the use of spring waters in crystalline basement rocks in Oke Igbo in south western Nigeria. Environmental Earth Sciences, 79(18), 1-20.

Rao, N.S., 2011. PIG: a numerical index for dissemination of groundwater contamination zones. Hydrological Processes, 26(22), 3344-3350.

Reta, G., Dong, X., Li, Z., Bo, H., Yu, D., Wan, H., Su B., 2019. Application of single factor and multi-factor pollution indices assessment for human-impacted river basins: water quality classification and pollution indicators. Nature Environment and Pollution Technology, 18(3), 1063-1072.

Sahoo, M.M., Swain, B.S., 2020. Modified heavy metal Pollution index (m-HPI) for surface water Quality in river basins, India. Environmental Science and Pollution Research, 27(13), 15350-15364.

Sawut, R., Kasim, N., Maihemuti, B., Hu, L., Abliz, A., Abdujappar, A., Kurban, M., 2018. Pollution characteristics and health risk assessment of heavy metals in the vegetable bases of northwest China. Science of the Total Environment, 642(1), 864-878.

Shukla, S., Saxena, A., 2020. Appraisal of groundwater quality with human health risk assessment in parts of Indo Gangetic Alluvial Plain, North India. Archives of Environmental Contamination and Toxicology, 80(1), $55-73$.

Solangi, G.S., Siyal, A.A., Babar, M.M., Siyal P., 2019. Application of water quality index, synthetic pollution index, and geospatial tools for the assessment of drinking water quality in the Indus Delta, Pakistan. Environmental monitoring and assessment, 191(12), 1-17.

Solangi, G.S., Siyal, A.A., Babar, M.M., Siyal, P., 2018. Evaluation of surface water quality using the water quality index (WQI) and the synthetic pollution index (SPI): a case study of Indus Delta region of Pakistan. Desalination and Water Treatment, 118(1) 39-48.

Swati, S., Umesh, S., 2015. Nemerow's pollution index: for ground water quality assessment. Journal of Environmental Science and Pollution Research, 1(1), 23-31.

World Health Organization., 2017. Guidelines for drinking-water quality: 4th edition, incorporating the first addendum. Typeset by Interligar, Brazil. $631 \mathrm{pp}$.

Yang, Q., Zhang, J., Hou, Z., Lei, X., Tai, W., Chen, W., Chen, T., 2017. Shallow groundwater quality assessment: use of the improved Nemerow pollution index, wavelet transform and neural networks. Journal of Hydro Informatics, 19(5), 784-794.

Zhang, Y., Chu, C., Li, T., Xu, S., Liu, L., Ju, M., 2017. A water quality management strategy for regionally protected water through health risk assessment and spatial distribution of heavy metal pollution in 3 marine reserves. Science of the Total Environment, 599(1), 721-731. 